\title{
Chilled Storage Induced Changes in Functional Properties of Fresh Water Eel (Mastacembelus armatus)
}

\author{
Rohini Mugale*, S.B. Patange, V.R. Joshi, G.N. Kulkarni and M.M. Shirdhankar \\ Department of Fish Processing Technology and Microbiology, College of Fisheries, \\ Shirgaon, Ratnagiri - 415629, Maharashtra, India \\ *Corresponding author
}

\section{Keywords \\ Eel fish, Functional properties, Ice storage}

\section{Article Info}

Accepted:

07 February 2018

Available Online:

10 March 2018

\section{A B S T R A C T}

The changes in functional properties viz. solubility, total sulfhydryl groups, $\mathrm{Ca}^{2+}$ ATPase activity, emulsion activity index (EAI), emulsion capacity (EC), viscosity, foam volume stability (FVS), foam volume capacity, gelation, water holding capacity (WHC) of muscle proteins from fresh water fish eel (Mastacembelus armatus) during ice storage was evaluated for a period of 16 days with the analysis of each parameter monitored for every alternate day. The solubility of muscle proteins i.e. MFP decreased from 59.16 to 51.89 $\mathrm{mg} / \mathrm{g}$ during chill storage. The gel strength of MFP decreased slowly from 250 to $247 \mathrm{~g} . \mathrm{cm}$ during first 4 days and then markedly decreased from 240 to 100 g.cm from $6^{\text {th }}$ day onwards up to $16^{\text {th }}$ day of storage. The total sulfhydryl groups of MFP fraction of eel muscle proteins decreased steadily during ice storage. The $\mathrm{Ca}^{2+}$ ATPase activity of actomyosin gradually decreased during storage. The emulsion activity index (EAI) of MFP and SPP fraction at concentration of 2.5 and $5.0 \mathrm{mg} / \mathrm{ml}$ also decreased continuously from 2.8 to 2.0 and 3.1 to $1.3 \mathrm{~m}^{2} / \mathrm{g}$ and 2.5 to 1.4 and 2.2 to $1.0 \mathrm{~m}^{2} / \mathrm{g}$ respectively. The emulsion stability (ES) of MFP and SPP fraction at concentration of 2.5 and $5.0 \mathrm{mg} / \mathrm{ml}$ decreased gradually from 55 to 28 and 60 to 40 and 32 to 15 and 40 to 20 min respectively during chill storage. The foaming expansion and foaming volume stability (FVS) at concentration of $5.0 \mathrm{mg} / \mathrm{ml}$ showed decreasing trend during chill storage. The viscosity of MFP and SPP at concentration of $5.0 \mathrm{mg} / \mathrm{ml}$ decreased gradually during chill storage. The water holding capacity (WHC) of muscle also reduced during chill storage. The result of fish with respect to functional properties showed noticeable changes during ice storage.

\section{Introduction}

The spiny eel, Mastacembelus armatus is one of the most common species of fresh water eel found in Asia. Demand for the fish almost always exceeds supply, particularly in India and its neighbouring countries such as Pakistan, Sri-Lanka and Bangladesh, although the fish has also been reported in Myanmar,
Thailand, Malaysia and Southern China. In northern and eastern India, the fish is very popular when sold alive; it occurs in a variety of freshwater habitats in the plains as well as in hills of India (Talwar and Jhingran, 1991).

Proteins are endowed with a number of physico-chemical and functional characteristics, which make them suitable for 
varied food applications such as thickeners, emulsifiers etc. The functional properties of eel muscle were evaluated in order to examine its potential in the preparation of emulsion or sausage type foods. Fish proteins are unique in nature and exhibit high degree of functional properties. Functional properties can affect the processing and behaviour of proteins in the food system as judged by the final quality of the product (Kinsella, 1981). Many proteins with different functional and biological activities share common structural elements (Richardson, 1981). Post harvest changes in fish muscle affect the quality of protein and hence its functional properties (Partiban et al., 2005).

The changes in functional properties of fish proteins during ice storage have been reported in hake (Crupkin et al., 1981), threadfin bream (Yongswawatdigul and Park, 2002), tilapia (Parthiban, et al., 2005, 2015), Atlantic salmon (Wang et al., 2005), rohu (Mohan et al., 2006) and L. calbasu (Yathavamoorthy et al., 2012). In view of limited literature available on changes in functional properties in eel fish proteins during ice storage, the present study investigates the changes in physico-chemical and functional properties of eel during chill storage.

\section{Materials and Methods}

Fresh eel (Mastacembelus armatus) harvested from Krishna River in Sangli district and brought in ice condition to Ratnagiri fish landing center were purchased. The fish had total length of 30 to $55 \mathrm{~cm}$ and weight ranged between $225 \pm 13.22 \mathrm{~g}$.

Fishes were de-skinned and filleted. The fillets were minced in a kitchen mixer/grinder and boneless meat was used under a temperature of $2-4^{\circ} \mathrm{C}$ throughout the experiment. Extraction of muscle protein fraction was estimated according to the method of King and Poulter (1985).Protein determination of MFP and SPP extracts were estimated according to Gornall et al., (1948) by Biuret method. Extraction of natural actomyosin was prepared according to the method described by Benjakul et al., (1997).

The ATPase assay of actomyosin was estimated according to the method of MacDonald and Lanier (1994). Inorganic phosphates were estimated by the method of Fiske and Subbarow (1925). The total SH groups of myofibrillar protein fraction were estimated according to Sedlak and Lindsay (1968).

The ability of the proteins, SPP and MFP to form emulsion was estimated as emulsion activity index (EAI) according to the method of Pearce and Kinsella (1978) and as per modification of Cameron et al., (1991). About $20 \mathrm{ml}$ sample was prepared for estimation of viscosity of salt soluble and water-soluble protein at different concentrations (2.5 and 5.0 $\mathrm{mg} / \mathrm{ml}$ ). It was determined with a (Model DV II + Pro, Brookfield) viscometer at shear rate $100 \mathrm{rpm}$ as described by Mohan et al., (2006). Foamability of the protein was determined by the method of Wild and Clark, (1996).The water- washed fish mince was used to get the concentrate of MFP. Heat-induced gels were prepared from MFP concentrate by grinding with $3 \%$ Sodium chloride for $2 \mathrm{~min}$ at $4^{\circ} \mathrm{C}$ (Lan et al., 1995).Water holding capacity (WHC) of mince was carried out by the method of Kocher and Foegeding (1993) with slight modification. The data of experiment was analyzed by Man-Whitney test and t-test (Zar, 2005).

\section{Results and Discussion}

\section{Solubility of protein}

The initial solubility of sarcoplasmic and myofibrillar fractions were observed to be 
44.93 and $59.16 \mathrm{mg} / \mathrm{g}$ respectively for the fresh eel stored in ice (Fig. 1). The SPP showed decreasing trend throughout the storage $(p<0.05)$. The decrease in solubility of SPP could be attributed to its instability due to the aggregation behavior under the conditions of storage and subsequent leaching out in the melt ice (Mohan et al., 2006; Parthiban et al., 2015).

The solubility of MFP of eel meat showed gradual decreasing trend $(\mathrm{p}<0.05)$. The solubility of proteins during ice storage decreased by $3 \%$ in two days and it remained almost constant up to 8 days, then further it decreased steadily up to $16^{\text {th }}$ day. By the end of 16 days of storage, $13 \%$ of MFP became insoluble. According to Partiban et al., (2005), the solubility of proteins during ice storage decreased by $8 \%$ in two days in tilapia stored in ice and it remained almost constant up to 7 days. By the end of 14 days of storage, $24 \%$ of total salt soluble proteins became insoluble. A similar decrease in salt soluble proteins of croaker and pink perch during ice storage was observed by Srikar (1979). Mohan et al., (2006) noted decreasing trend in protein solubility of rohu during iced storage. Parthiban et al., (2015) observed that the total soluble proteins of tilapia decreased during storage in ice.

\section{$\mathrm{Ca}^{2+}$ ATPase activity of actomyosin of eel}

ATPase activity has often been monitored as an indicator of the extent of myosin unfolding (denaturation) and aggregation (Lanier, 1986). $\mathrm{Ca}^{2+}$ ATPase are localized in the myosin head region and play a significant role in the muscle contraction. Any alteration in the structural integrity of myosin affects the activity of enzyme and is widely used as the measure of myosin integrity (Nagai et al., 1990 and Benjakul et al., 1997). The $\mathrm{Ca}^{2+}$ ATPase activity of actomyosin of eel in the present study showed decreasing trend during storage of fish. The decrease in the activity was marginal up to initial four days of storage in ice as was evidenced from the gel strength value observed for the sample on the $4^{\text {th }}$ day. Thereafter, it decreased significantly $(\mathrm{p}<$ $0.05)$ from initial value of $0.50 \mu$ mole $\mathrm{Pi} / \mathrm{mg}$ protein $/ \mathrm{min}$ on the $1^{\text {st }}$ day of storage to 0.20 $\mu$ mole $\mathrm{Pi} / \mathrm{mg}$ protein/min on $16^{\text {th }}$ day of storage (Fig. 2).

The results of the present study revealed denaturation of myofibrillar proteins particularly myosin that underwent denaturation during ice storage. The loss in ATPase activity may also be attributed to the tertiary structural changes caused by ice storage and increase in the ionic strength of the system. Further, rearrangement of proteins via protein-protein interactions is also presumed to contribute to the loss in ATPase activity (Benjakul and Bauer, 2000).

\section{Total sulfhydryl content of MFP of eel}

In the present study, the content of total sulfhydryl groups of MFP fraction of eel decreased steadily from initial value of 48.27 $\mu$ mole $\mathrm{SH} / \mathrm{g}$ protein on the $1^{\text {st }}$ day to 45.95 $\mu$ mole $\mathrm{SH} / \mathrm{g}$ protein on $16^{\text {th }}$ day of chill storage (Fig. 3). The decrease in sulfhydryl content was coincidental with the decrease in $\mathrm{Ca}^{2+}$-ATPase activity. It was presumed that conformational changes of myosin, especially in the head region occurred rapidly. These changes probably resulted in the exposure of reactive sulfhydryl groups, which were prone to oxidation of disulfide interchange (Benjakul et al., 2003). Wang et al., (2005) observed that total SH groups increased during first two days, followed by gradual decrease in farmed Atlantic salmon (Salmo salar) during storage at $4^{\circ} \mathrm{C}$. Mohan et al., (2006) reported decrease in -SH groups of rohu during 11 days of ice storage. Parthiban et al., (2015) reported that $\mathrm{SH}$ groups content was $23 \mu$ moles $/ \mathrm{min} / \mathrm{mg}$ actomyosin which increased on $4^{\text {th }}$ day of iced 
storage and the increase was more than five times on day 14 indicating protein denaturation.

The decrease in sulfhydryl groups with a concomitant oxidation resulted in the formation of disulfide bonds through oxidation of sulfhydryl groups or disulfide inter changes (Hayagawa and Nakai, 1985). Changes in $\mathrm{SH}$ groups are an indication of either the formation of disulfide bond or fresh exposure of reactive $\mathrm{SH}$ groups to the bulk solvent from the interior of the protein molecule (Murthy et al., 2012).

Emulsion activity index (EAI) and Emulsion stability (ES) of SPP and MFP of eel during chill storage

The emulsifying properties of proteins are evaluated by several methods, such as size distribution of oil droplets formed, emulsifying activity, emulsion capacity and emulsion stability (Kinsella and Melachouris, 1976). In the present study, the ES was calculated on the basis of time taken for attaining half the initial OD at 500 (Pearce and Kinsella, 1978). Myosin and actomyosin molecules by virtue of their structure and conformation due to both hydrophobic and hydrophilic residues, act as excellent emulsifier (Galluzzo and Regenstein, 1978).

In the present study, the EAI of MFP of eel at concentration of $2.5 \mathrm{mg} / \mathrm{ml}$ decreased gradually from $2.8 \mathrm{~m}^{2} / \mathrm{g}$ on $1^{\text {st }}$ day to $2.0 \mathrm{~m}^{2} / \mathrm{g}$ on $16^{\text {th }}$ day of storage. EAI of MFP of eel at concentration of $5.0 \mathrm{mg} / \mathrm{ml}$ decreased gradually from $3.1 \mathrm{~m}^{2} / \mathrm{g}$ on $1^{\text {st }}$ day of storage to $1.3 \mathrm{~m}^{2} / \mathrm{g}$ on $16^{\text {th }}$ day of chilled storage (Table 1) and the EAI of SPP of eel at concentration of $2.5 \mathrm{mg} / \mathrm{ml}$ was observed to be $2.5 \mathrm{~m}^{2} / \mathrm{g}$ on the $1^{\text {st }}$ day which decreased to 1.4 $\mathrm{m}^{2} / \mathrm{g}$ on $16^{\text {th }}$ day. EAI of SPP was recorded at concentration of $5.0 \mathrm{mg} / \mathrm{ml}$ as $2.2 \mathrm{~m}^{2} / \mathrm{g}$ on the $1^{\text {st }}$ day which also decreased to $1.0 \mathrm{~m}^{2} / \mathrm{g}$ on $16^{\text {th }}$ day of chilled storage (Table 1 ). EAI was reported to have a clear correlation with surface hydrophobicity, solubility and viscosity of the protein (Mohan et al., 2008). The EAI decreased in the present study which may be attributed to the decrease in viscosity and solubility of MFP during storage.

The emulsion stability of MFP of eel at concentration of $2.5 \mathrm{mg} / \mathrm{ml}$ decreased steadily from initial value of $55 \mathrm{~min}$ on $1^{\text {st }}$ day of storage to $28 \mathrm{~min}$ on $16^{\text {th }}$ day of storage. Emulsion stability of MFP at concentration of $5.0 \mathrm{mg} / \mathrm{ml}$ changed from initial value of 60 $\min$ on $1^{\text {st }}$ day of storage to $40 \mathrm{~min}$ on $16^{\text {th }}$ day of chill storage (Table 2). The emulsion stability of SPP of eel at concentration of 2.5 $\mathrm{mg} / \mathrm{ml}$ decreased gradually from initial value of $38 \mathrm{~min}$ on $1^{\text {st }}$ day of storage to $17 \mathrm{~min}$ on $16^{\text {th }}$ day of storage. Emulsion stability of SPP at concentration of $5.0 \mathrm{mg} / \mathrm{ml}$ changed from initial value of $40 \mathrm{~min}$ on $1^{\text {st }}$ day of storage to 20 min on $16^{\text {th }}$ day of chilled storage (Table 2).

The decrease in EAI could be related to the formation of disulfide bond between the protein molecules by the oxidation of $\mathrm{SH}$ groups exposed during protein unfolding during the initial periods of storage. Tendency of the proteins to aggregate resulted in decreased emulsion stability. The low temperature induced denaturation of proteins in mince of Indian oil sardine (Sardinella longiceps) resulted in the reduction of emulsion capacity of extract (Mathew and Prakash, 2007).

Parthiban et al., (2005) observed that the EAI increased by 2-3 times during the storage of fish in ice up to 7 day and after that EAI decreased and continued till the end of storage period. Similar results were observed by Mohan et al., (2006) where the emulsion stability of the protein gradually decreased during storage of rohu fish in ice. 
Table.1 Changes in emulsion activity index of MFP and SPP of eel

\begin{tabular}{|c|c|c|c|c|}
\hline \multirow[t]{3}{*}{ Storage days } & \multicolumn{2}{|c|}{ EAI $\left(\mathrm{m}^{2} / \mathrm{g}\right)$ of MFP } & \multicolumn{2}{|c|}{ EAI $\left(\mathrm{m}^{2} / \mathrm{g}\right)$ of SPP } \\
\hline & \multicolumn{4}{|c|}{ Protein concentration } \\
\hline & $2.5 \mathrm{mg} / \mathrm{ml}$ & $5.0 \mathrm{mg} / \mathrm{ml}$ & $2.5 \mathrm{mg} / \mathrm{ml}$ & $5.0 \mathrm{mg} / \mathrm{ml}$ \\
\hline 0 & $2.8 \pm 0.05$ & $3.1 \pm 0.14$ & $2.5 \pm 0.15$ & $2.2 \pm 0.18$ \\
\hline 2 & $2.7 \pm 0.08$ & $3.0 \pm 0.12$ & $2.4 \pm 0.11$ & $2.0 \pm 0.08$ \\
\hline 4 & $2.5 \pm 0.03$ & $2.8 \pm 0.08$ & $2.3 \pm 0.09$ & $1.9 \pm 0.05$ \\
\hline 6 & $2.4 \pm 0.11$ & $2.7 \pm 0.05$ & $2.1 \pm 0.12$ & $1.8 \pm 0.11$ \\
\hline 8 & $2.3 \pm 0.08$ & $2.6 \pm 0.16$ & $1.8 \pm 0.05$ & $1.7 \pm 0.16$ \\
\hline 10 & $2.2 \pm 0.15$ & $1.9 \pm 0.12$ & $1.7 \pm 0.18$ & $1.6 \pm 0.20$ \\
\hline 12 & $2.1 \pm 0.03$ & $1.5 \pm 0.07$ & $1.5 \pm 0.06$ & $1.4 \pm 0.14$ \\
\hline 14 & $2.0 \pm 0.06$ & $1.4 \pm 0.11$ & $1.3 \pm 0.15$ & $1.2 \pm 0.17$ \\
\hline 16 & $2.0 \pm 0.04$ & $1.3 \pm 0.15$ & $1.4 \pm 0.03$ & $1.0 \pm 0.07$ \\
\hline
\end{tabular}

Table.2 Changes in emulsion stability of MFP and SPP of eel

\begin{tabular}{|c|c|c|c|c|}
\hline \multirow{2}{*}{ Storage days } & \multicolumn{3}{|c|}{ ES (min) of MFP } & \multicolumn{2}{c|}{ ES (min) of SPP } \\
\cline { 2 - 5 } & \multicolumn{4}{|c|}{ Protein concentration } \\
\hline $\mathbf{0}$ & $\mathbf{2 . 5} \mathbf{~ m g / m l}$ & $\mathbf{5 . 0} \mathbf{~ m g / m l}$ & $\mathbf{2 . 5} \mathbf{~ m g} / \mathbf{m l}$ & $\mathbf{5 . 0 ~} \mathbf{~ m g} / \mathbf{m l}$ \\
\hline $\mathbf{2}$ & $55 \pm 0.57$ & $60 \pm 0.33$ & $32 \pm 0.88$ & $40 \pm 0.57$ \\
\hline $\mathbf{4}$ & $52 \pm 0.57$ & $58 \pm 0.88$ & $30 \pm 0.33$ & $38 \pm 0.88$ \\
\hline $\mathbf{6}$ & $50 \pm 0.33$ & $55 \pm 0.57$ & $27 \pm 0.57$ & $36 \pm 0.57$ \\
\hline $\mathbf{8}$ & $48 \pm 0.57$ & $52 \pm 0.57$ & $24 \pm 0.88$ & $32 \pm 0.88$ \\
\hline $\mathbf{1 0}$ & $46 \pm 0.33$ & $50 \pm 0.57$ & $22 \pm 0.57$ & $30 \pm 0.88$ \\
\hline $\mathbf{1 2}$ & $40 \pm 0.57$ & $48 \pm 0.57$ & $22 \pm 0.57$ & $27 \pm 0.57$ \\
\hline $\mathbf{1 4}$ & $35 \pm 0.57$ & $45 \pm 0.57$ & $20 \pm 0.88$ & $24 \pm 0.57$ \\
\hline $\mathbf{1 6}$ & $30 \pm 0.57$ & $43 \pm 0.33$ & $17 \pm 0.57$ & $22 \pm 0.57$ \\
\hline & $28 \pm 0.88$ & $40 \pm 0.88$ & $15 \pm 0.57$ & $20 \pm 0.57$ \\
\hline
\end{tabular}

Table.3 Changes in viscosity of MFP and SPP of eel

\begin{tabular}{|c|c|c|c|c|}
\hline \multirow[t]{3}{*}{ Storage days } & \multicolumn{2}{|c|}{ Viscosity (cP) of MFP } & \multicolumn{2}{|c|}{ Viscosity (cP) of SPP } \\
\hline & \multicolumn{2}{|c|}{ Protein concentration } & \multicolumn{2}{|c|}{ Protein concentration } \\
\hline & $2.5 \mathrm{mg} / \mathrm{ml}$ & $5.0 \mathrm{mg} / \mathrm{ml}$ & $2.5 \mathrm{mg} / \mathrm{ml}$ & $5.0 \mathrm{mg} / \mathrm{ml}$ \\
\hline $\mathbf{0}$ & $2.3 \pm 0.05$ & $2.5 \pm 0.05$ & $1.9 \pm 0.12$ & $2.3 \pm 0.05$ \\
\hline 2 & $2.2 \pm 0.08$ & $2.4 \pm 0.08$ & $1.8 \pm 0.08$ & $2.2 \pm 0.03$ \\
\hline 4 & $2.2 \pm 0.06$ & $2.3 \pm 0.07$ & $1.7 \pm 0.03$ & $2.1 \pm 0.06$ \\
\hline 6 & $2.1 \pm 0.08$ & $2.3 \pm 0.12$ & $1.6 \pm 0.05$ & $1.9 \pm 0.08$ \\
\hline 8 & $2.0 \pm 0.05$ & $2.2 \pm 0.05$ & $1.5 \pm 0.03$ & $1.8 \pm 0.02$ \\
\hline 10 & $1.9 \pm 0.09$ & $2.1 \pm 0.06$ & $1.3 \pm 0.07$ & $1.7 \pm 0.03$ \\
\hline 12 & $1.8 \pm 0.12$ & $2.1 \pm 0.02$ & $1.2 \pm 0.06$ & $1.5 \pm 0.12$ \\
\hline 14 & $1.7 \pm 0.11$ & $2.2 \pm 0.03$ & $1.2 \pm 0.02$ & $1.4 \pm 0.11$ \\
\hline 16 & $1.6 \pm 0.03$ & $2.0 \pm 0.08$ & $1.1 \pm 0.07$ & $1.3 \pm 0.03$ \\
\hline
\end{tabular}


Table.4 Changes in foam expansion of MFP and SPP of eel

\begin{tabular}{|c|c|c|c|c|}
\hline \multirow[t]{3}{*}{ Storage days } & \multicolumn{2}{|c|}{ Foam expansion (\%) of MFP } & \multicolumn{2}{|c|}{ Foam expansion (\%) of SPP } \\
\hline & \multicolumn{2}{|c|}{ Protein concentration } & \multicolumn{2}{|c|}{ Protein concentration } \\
\hline & $2.5 \mathrm{mg} / \mathrm{ml}$ & $5.0 \mathrm{mg} / \mathrm{ml}$ & $2.5 \mathrm{mg} / \mathrm{ml}$ & $5.0 \mathrm{mg} / \mathrm{ml}$ \\
\hline 0 & $3.1 \pm 0.06$ & $3.0 \pm 0.03$ & $2.4 \pm 0.05$ & $2.3 \pm 0.05$ \\
\hline 2 & $2.9 \pm 0.05$ & $2.8 \pm 0.03$ & $2.3 \pm 0.05$ & $2.2 \pm 0.05$ \\
\hline 4 & $2.8 \pm 0.03$ & $2.7 \pm 0.06$ & $2.2 \pm 0.03$ & $1.8 \pm 0.05$ \\
\hline 6 & $2.5 \pm 0.05$ & $2.6 \pm 0.05$ & $2.0 \pm 0.03$ & $1.6 \pm 0.03$ \\
\hline 8 & $2.1 \pm 0.05$ & $2.5 \pm 0.03$ & $1.9 \pm 0.03$ & $1.5 \pm 0.05$ \\
\hline 10 & $2.0 \pm 0.06$ & $2.3 \pm 0.05$ & $1.8 \pm 0.05$ & $1.3 \pm 0.03$ \\
\hline 12 & $1.7 \pm 0.06$ & $2.1 \pm 0.03$ & $1.6 \pm 0.03$ & $1.2 \pm 0.03$ \\
\hline 14 & $1.6 \pm 0.05$ & $1.9 \pm 0.12$ & $1.4 \pm 0.05$ & $1.1 \pm 0.03$ \\
\hline 16 & $1.5 \pm 0.03$ & $1.7 \pm 0.03$ & $1.2 \pm 0.05$ & $1.0 \pm 0.03$ \\
\hline
\end{tabular}

Table.5 Changes in foam volume stability of MFP and SPP of eel

\begin{tabular}{|c|c|c|c|c|}
\hline \multirow{3}{*}{$\begin{array}{l}\text { Storage } \\
\text { days }\end{array}$} & \multicolumn{2}{|c|}{ Foam Volume Stability (\%) of MFP } & \multicolumn{2}{|c|}{ Foam Volume Stability (\%) of SPP } \\
\hline & \multicolumn{2}{|c|}{ Protein concentration } & \multicolumn{2}{|c|}{ Protein concentration } \\
\hline & $2.5 \mathrm{mg} / \mathrm{ml}$ & $5.0 \mathrm{mg} / \mathrm{ml}$ & $2.5 \mathrm{mg} / \mathrm{ml}$ & $5.0 \mathrm{mg} / \mathrm{ml}$ \\
\hline 0 & $60.5 \pm 0.38$ & $65.3 \pm 0.12$ & $28.8 \pm 0.17$ & $35.6 \pm 0.20$ \\
\hline 2 & $59.7 \pm 0.72$ & $65.4 \pm 0.76$ & $28.8 \pm 0.23$ & $35.2 \pm 0.20$ \\
\hline 4 & $59.5 \pm 0.27$ & $65.2 \pm 0.63$ & $27.2 \pm 0.58$ & $34.6 \pm 0.41$ \\
\hline 6 & $58.9 \pm 0.34$ & $64.8 \pm 0.46$ & $27.1 \pm 0.28$ & $34.3 \pm 0.24$ \\
\hline 8 & $58.5 \pm 0.82$ & $64.5 \pm 0.40$ & $26.8 \pm 0.43$ & $33.8 \pm 0.26$ \\
\hline 10 & $58.2 \pm 0.66$ & $64.3 \pm 0.40$ & $26.5 \pm 0.65$ & $33.5 \pm 0.29$ \\
\hline 12 & $57.5 \pm 0.53$ & $63.2 \pm 0.27$ & $26.3 \pm 0.37$ & $32.2 \pm 0.20$ \\
\hline 14 & $56.6 \pm 0.78$ & $62.8 \pm 0.51$ & $25.9 \pm 0.20$ & $32.0 \pm 0.66$ \\
\hline 16 & $56.2 \pm 0.75$ & $62.2 \pm 0.57$ & $25.7 \pm 0.40$ & $31.8 \pm 0.57$ \\
\hline
\end{tabular}

Fig.1 Changes in concentration of MFP and SPP of eel

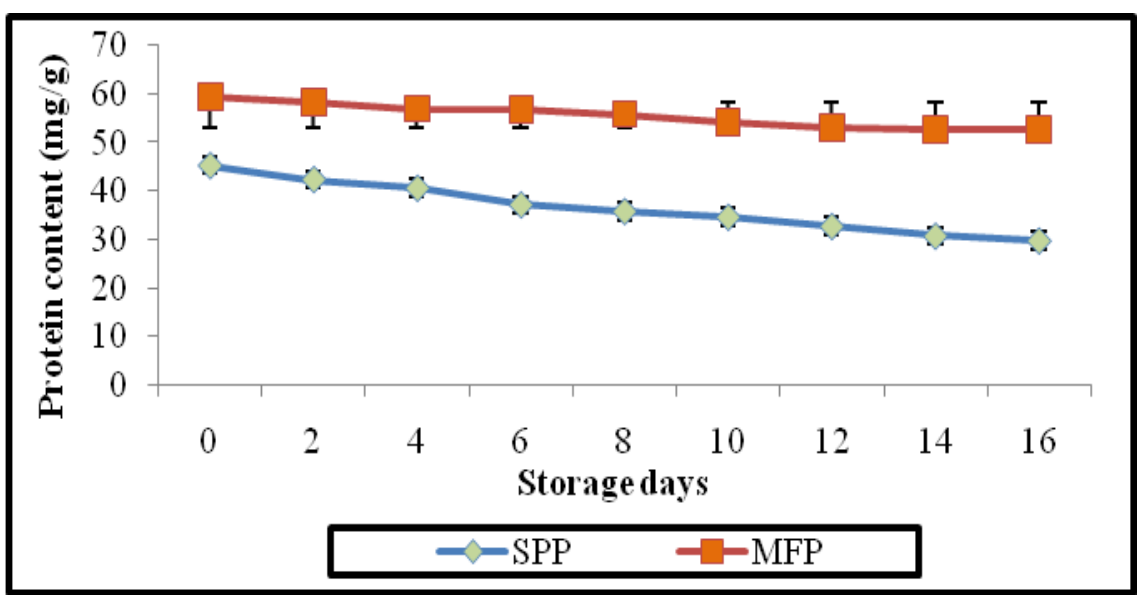


Fig.2 Changes in $\mathrm{Ca}^{2+}$ ATPase activity of actomyosin of eel

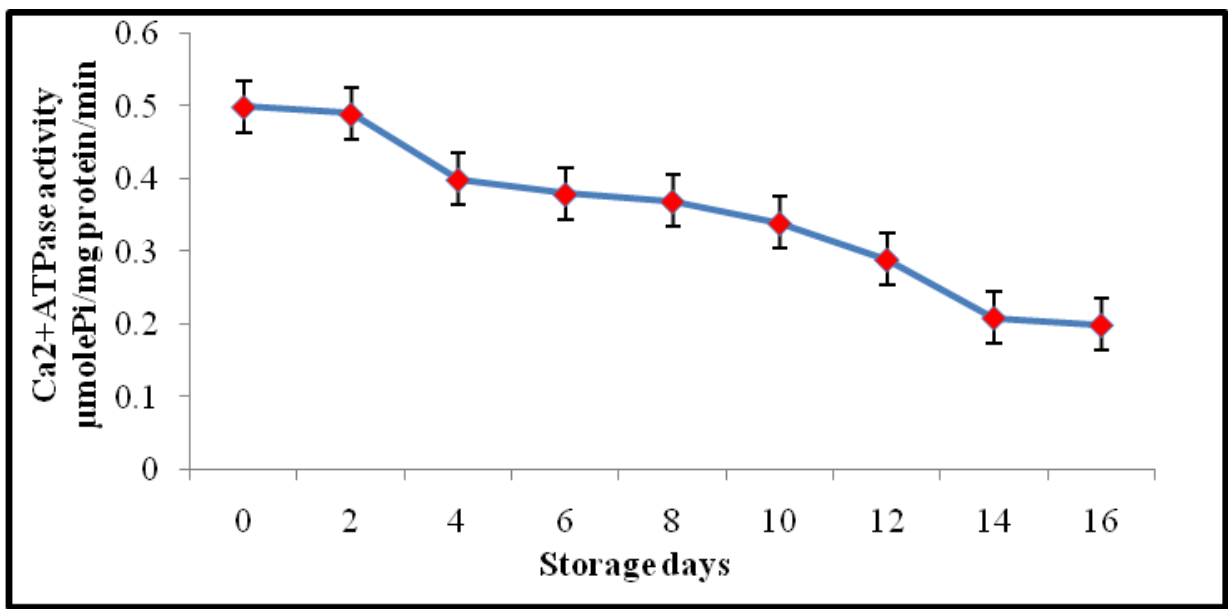

Fig.3 Changes in total sulfhydryl groups of MFP of eel

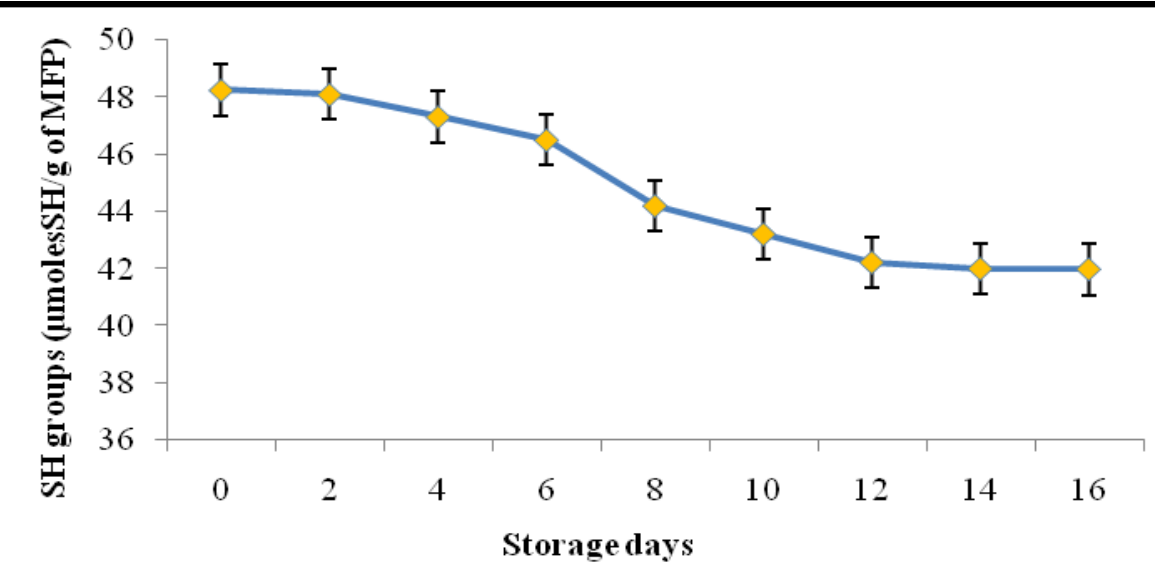

Fig.4 Changes in gel strength of eel mince

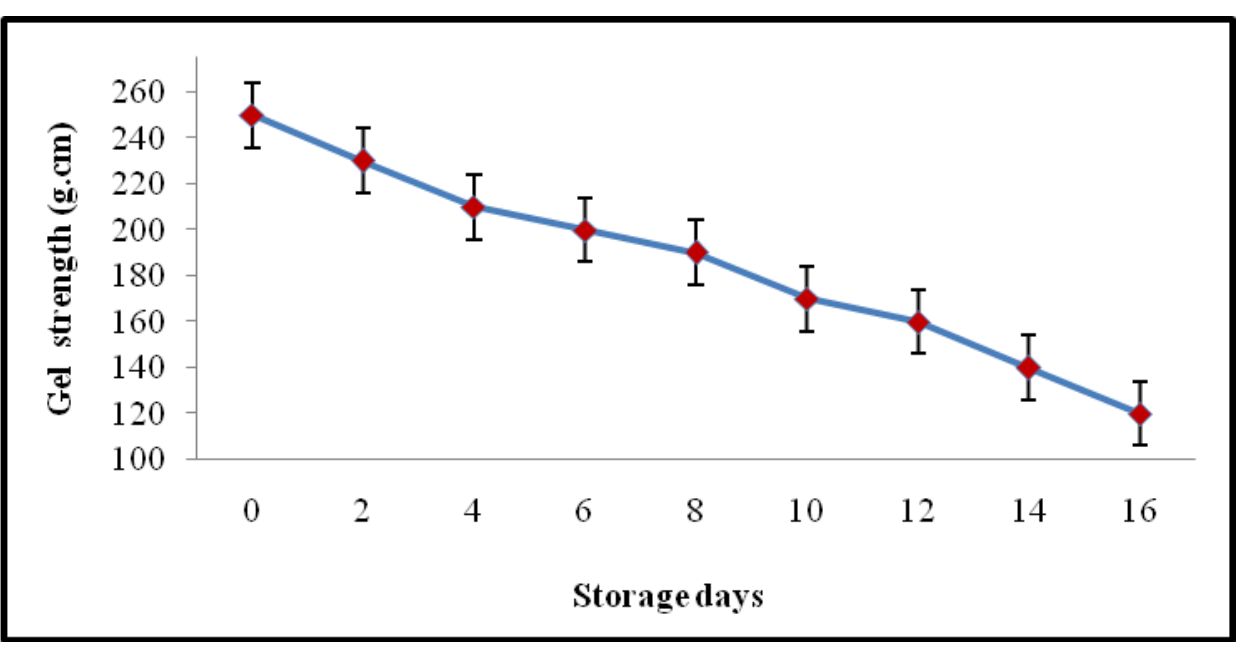


Fig.5 Changes in water holding capacity of eel mince

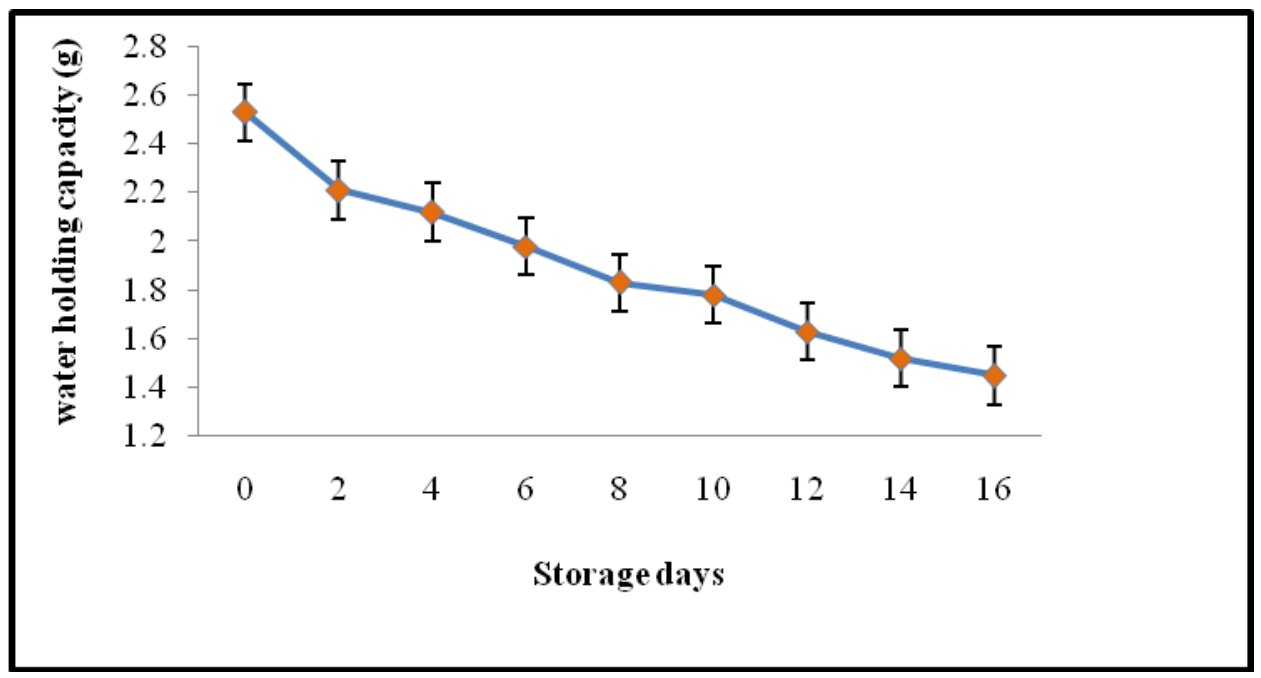

Viscosity of SPP and MFP of eel proteins

The viscosity of a solution relates to its resistance to flow under an applied force (or shear stress). Myosin present in muscle proteins is the major contributor to the viscosity of aqueous muscle extracts. In the present study, the viscosity of eel MFP at concentration of $2.5 \mathrm{mg} / \mathrm{ml}$ decreased gradually from initial value of $2.3 \mathrm{cP}$ on the $1^{\text {st }}$ day to $1.6 \mathrm{cP}$ on $16^{\text {th }}$ day of storage. Viscosity of eel MFP at the concentration of $5.0 \mathrm{mg} / \mathrm{ml}$ decreased steadily from initial value of $2.5 \mathrm{cP}$ on $1^{\text {st }}$ day to $2.0 \mathrm{cP}$ on $16^{\text {th }}$ day of storage (Table 3) and the viscosity of eel SPP estimated at concentration of 2.5 $\mathrm{mg} / \mathrm{ml}$ decreased gradually from initial value of $1.9 \mathrm{cP}$ on the $1^{\text {st }}$ day to $1.1 \mathrm{cP}$ on $16^{\text {th }}$ day of storage. But, at SPP concentration of 5.0 $\mathrm{mg} / \mathrm{ml}$, it decreased from initial value of 2.3 $\mathrm{cP}$ on $1^{\text {st }}$ day to $1.3 \mathrm{cP}$ on $16^{\text {th }}$ day of storage (Table 3). The results showed that with the increase in the concentration of protein there was increase the viscosity of protein.

Chalmers et al., (1992) reported the highest viscosity after 6 days of storage and gradual decrease thereafter up to $9^{\text {th }}$ day of storage of cod. Mehta et al., (2011) observed the changes in viscosity of muscle protein of freshwater fishes (Indian major carps) decreases during 22 days of ice storage. Mohan et al., (2006) observed gradual change in viscosity of MFP for both concentrations i.e. $2.5 \mathrm{mg} / \mathrm{ml}$ and $5 \mathrm{mg} / \mathrm{ml}$ during iced storage of rohu (Labeo rohita).

\section{Foam expansion and foam volume stability of SPP and MFP during chill storage}

In the present study, the foam expansion of MFP of eel at concentration of $2.5 \mathrm{mg} / \mathrm{ml}$ decreased progressively from initial value of $3.1 \%$ on the $1^{\text {st }}$ day to $1.5 \%$ on $16^{\text {th }}$ day of storage. Its value at the concentration of 5.0 $\mathrm{mg} / \mathrm{ml}$ decreased markedly from $3.0 \%$ on $1^{\text {st }}$ day to $1.7 \%$ on $16^{\text {th }}$ day of storage (Table 4) and the foam expansion of SPP of eel at concentration of $2.5 \mathrm{mg} / \mathrm{ml}$ decreased from initial value of $2.4 \%$ on $1^{\text {st }}$ day to $1.2 \%$ on $16^{\text {th }}$ day of storage. Its value at the concentration of $5.0 \mathrm{mg} / \mathrm{ml}$ decreased significantly from $2.3 \%$ on $1^{\text {st }}$ day to $1.0 \%$ at $16^{\text {th }}$ day of storage (Table 4).

Foam stability refers to the ability of proteins to stabilize foam against gravitational and mechanical stresses whereas, the foam volume stability of MFP of eel at concentration of $2.5 \mathrm{mg} / \mathrm{ml}$ ranged from 
$60.5 \%$ on $1^{\text {st }}$ day to $56.2 \%$ on $16^{\text {th }}$ day of storage. Foam volume stability of eel of MFP at concentration of $5.0 \mathrm{mg} / \mathrm{ml}$ ranged from initial value from $65.3 \%$ on $1^{\text {st }}$ day to $62.2 \%$ on $16^{\text {th }}$ day of storage (Table 5) and the foam volume stability of SPP of eel at concentration of $2.5 \mathrm{mg} / \mathrm{ml}$ decreased continuously from $28.8 \%$ on $1^{\text {st }}$ day to 25.7 $\%$ on $16^{\text {th }}$ day of storage. Foam volume stability of eel of SPP at concentration of 5.0 $\mathrm{mg} / \mathrm{ml}$ decreased progressively from $35.6 \%$ on $1^{\text {st }}$ day to $31.8 \%$ on $16^{\text {th }}$ day of storage (Table 5). The most direct measure of Foam volume stability is the reduction in foam interfacial area as a function of time. Foamability of MFP $(5 \mathrm{mg} / \mathrm{ml})$ showed a concentration dependent increase but it decreased gradually during the storage period. The strength of the foam derived from MFP was higher than the SPP which might be due to the differences in the molecular weight of the proteins as the foam refers to maximum weight a column of foam can withstand before its collapses. Parthiban et al., (2005) observed a gradual decline in foamability during storage of tilapia fish under chilled condition. Mohan et al., (2006) noted that foamability of SPP was relatively stable during six days of storage and showed a gradual decline subsequently. Foam volume stability of SPP was found to be increasing during storage whereas, foamability of MFP at both concentrations of $2.5 \mathrm{mg} / \mathrm{ml}$ and 5.0 $\mathrm{mg} / \mathrm{ml}$ showed decreasing trend during storage period and FVS of MFP at both concentrations of $2.5 \mathrm{mg} / \mathrm{ml}$ and $5.0 \mathrm{mg} / \mathrm{ml}$ remained stable throughout the storage period.

\section{Gel strength of muscle proteins of MFP of eel fish}

Protein gelation refers to transformation of a protein from the sol state to a gel like usually high temperature, enzymes like transglutaminases or divalent cations under appropriate conditions facilitate this transformation. In the present study, gel strength of MFP of eel mince decreased with increase in storage time of fish in ice. It decreased slowly from first 4 days and then markedly decreased from initial 250 g.cm on $1^{\text {st }}$ day to 120 g.cm on $16^{\text {th }}$ day of storage (Fig. 4). Gel forming ability of fish proteins is an important functional property (Murthy et al., 2012). Benjakul et al., (2003) observed that the degradation of myosin results in an inferior gel network formation, causing a lower elasticity with poor water holding capacity in the gel matrix.

Yongswawatdigul and Park (2002) noted the steady decrease in breaking force and deformation of washed mince of threadfin bream with in storage time. Parthiban et al., (2005) observed gradual decrease in gel strength with increase in length of storage of tilapia fish in ice. Mehta et al., (2011) noted that there was a significant decrease in gel strength values in all the three species of Indian major carp at the end of 22 days of ice storage.

\section{Water holding capacity of muscle proteins of eel fish (WHC)}

Myofibrils are the largest water-holding filament lattices and most of the water in the meat is held within the myofibrils in the narrow channels between the filaments (Sankar, 2009). In the present study, the water holding capacity of eel mince during chill storage decreased continuously from initial value of $2.53 \mathrm{~g} / \mathrm{g}$ muscle on $1^{\text {st }}$ day to $1.45 \mathrm{~g} /$ $\mathrm{g}$ muscle on $16^{\text {th }}$ day of storage (Fig. 5).

Ramachandran et al., (2007) observed a value of $2.49 \mathrm{~g} / \mathrm{g}$ of WHC in group I $(500 \mathrm{~g})$ and $1.61 \mathrm{~g} / \mathrm{g}(1500 \mathrm{~g})$ of barracuda fish. The water, which is immobilized in the protein structure, is released as a result of protein denaturation consequent of protein unfolding 
(Partiban, 2005). During frozen storage water holding capacity of fish protein decreased due to denaturation and is supported by the increased thaw drip in frozen stored fish (Chang and Regenstein, 1997; Wang and Xiong, 1998; Benjakul et al., 2005).

Similar trend was observed by Partiban et al., (2005) with WHC of muscle protein of tilapia marginally increasing up to $4^{\text {th }}$ day of storage and then decreasing up to $10^{\text {th }}$ day, there was no further decrease. Further, Wang et al., (2005) observed that the water holding capacity increased initially and then decreased progressively thereafter until $7^{\text {th }}$ day and then increased again on $9^{\text {th }}$ day of storage.

\section{References}

Benjakul, S. and Bauer, F. 2000. Physicochemical and enzymatic changes of cod muscle proteins subjected to different freeze-thaw cycles. J. Food Sci. Agric., 80: 11431150 .

Benjakul, S., Seymour, T.A., Morrissey, M. T. and An, H. 1997. Physico-chemical changes in Pacific whiting muscle proteins during iced storage. J. Food Sci., 62: 729-733.

Benjakul, S., Visessanguan, W., Thongkaew, C and Tanaka, M. 2003. Comparative study on physico-chemical changes of muscle proteins from some tropical fish during frozen storage. Food Res Intl. 36: 787-95.

Benjakul, S., Visessanguan, W., Thongkaewa, C. and Tanaka, M. 2005. Effect of frozen storage on chemical and gelforming properties of fish commonly used for surimi production in Thailand. Food Hydrocolloids, 19:197-207.

Cameron, D. R., Weber, M. E., Idziak, E. S. Neufeld, R. J. and Cooper, D. G. 1991. Determination of interfacial areas in emulsions using turbid metric and droplet size data: Correction of the formula for emulsifying activity index. J. Agric. Food Chem., 39: 655-659.

Chalmers, M., Careche, M. and Mackie, I. 1992. Properties of actomyosin isolated from cod (Gadus morhua) after various periods of storage in ice. J. Sci. Food Agric., 58: 375-383.

Chang, C. C. and Regenstein, J. M. 1997. Water uptake, protein solubility and protein changes of cod mince stored on ice as affected by polyphosphates. $J$. Food Sci., 62: 305-9.

Crupkin, M., Barassi, C. A., Arguello, J. M. and Trucco, R. E. 1981. Effect of postrigor fish storage on ice on physicochemical properties of actomyosin. J. Sci. Food Agric. 33: 1129-1134.

Fiske, C. H. and Subbarow, Y. 1925. The colorimetric determination of phosphorus. J. Biol. Chem. 66: 375-400.

Galluzzo, S. J. and Regenstein, J. M. 1978. Role of chicken breast muscle proteins in meat emulsion formation: myosin, actin and synthetic actomyosin. J. Food Sci., 43: 1761-1765.

Gornall, A. G., Bardawill, C. J. and David, M. M. 1948. Determination of serum proteins by means of the biuret reaction. J. Biol. Chem. 177: 751-766.

Hayagawa, S. and Nakai, S. 1985. Contribution of hydrophobicity, net charge and sulfhydryl groups to thermal properties of ovalbumin. Canadian Inst. Food Sci. Technol. J., 18: 290-295.

King, D. R. and Poulter, R. G. 1985. Frozen storage of Indian mackerel (Rastrelliger kanagurta) and big eye (Periacanthus hamrur). Tropical Science, 25: 79-90.

Kinsella, J. E. 1981. Relation between structural and functional properties of food protein. In: Food Proteins (R.F. Fox, and J.J. Condon. Eds.), Applied science publishers, New York. pp 51103. 
Kocher, P. N. and Foegeding, E. A. 1993. Micro centrifuge based method for measuring water holding of protein gels. J. Food Sci., 58: 1040-1046.

Lan, Y. H., Novakofski, J., McCuskar, R. H., Brewer, M. S., Carr, T. R. and Mc Keith, F. K. 1995. Thermal gelation of pork, beef, fish, chicken and turkey muscles as affected by heating rate and pH. J. Food Sci., 60 (5): 936-940.

Lanier, T.C. 1986. Functional properties of surimi. Food Technol., 40: 107-114.

MacDonald, G. A. and Lanier, T. C. 1994. Actomyosin stabilization to freeze-thaw and heat denaturation by lactate salts. $J$. Food Sci. 59: 101-105.

Mathew, S. and Prakash, V. 2007. Changes in structural and functional attributes of fish mince proteins in presence of cosolvent during frozen storage. Int. J. Food properties, 10 (1): 47-59.

Mehta, N.K., Elavarasan, K., Reddy, A. M. and Shamasundar, B. A. 2011. Effect of ice storage on the functional properties of proteins from a few species of fresh water fish (Indian major carps) with special emphasis on gel forming ability. J. Food Sci. Technol., 51(4): 655-663.

Mohan, M., Ramachandran, D. and Sankar, T. V. 2006. Functional properties of Rohu (Labeo rohita) proteins during iced storage. Food Res. Intl., 39: 847-854.

Murthy, L. M., Panda, S. K. and Rajanna, K. B. 2012. Effect of cryoprotectants on the functional properties of proteins from tilapia (Oreochromis mossambicus) during frozen storage. Fish Technol., 49: 155-160.

Nagai, T., Kurata M., Nakamura, T., Ito T., Fujiki, K., Nakao, M. and Yano, T. 1990. Properties of myofibrillar protein from Japanese stingfish (Sebastes inermis) dorsal muscle. Food Res. Intl., 32: 401-405.

Parthiban, F., Sankar, T. V. and Anandan, P. 2015. Changes in soluble protein and actomyosin during chilled and frozen storage of tilapia (Oreochromis mossambicus). Fish. Technol., 52: 101108. Rossmann, M.G. and Argos, P. (1981) Ann. Rev. Biochem. 50-497.

Partiban, F., Sankar, T. V. and Anandan, P. 2005. Changes in the functional properties of tilapia (Oreochromis mossambicus) protein during storage in ice.Fish. Technol., 42 (2): 155-162.

Pearce, K. N. and Kinsella, J. E. 1978. Emulsifying properties of protein evaluation by a turbidimetric technique. J. Agric. Food Chem., 26: 716-723.

Ramachandran, D., Mohan, M. and Sankar, T. V. 2007. Physicochemical characteristics of muscle proteins from barracuda (Sphyraena jello) of different weight groups. LWT Food Sci Technol., 1418-1426.

Richardson J. S. 1981. The anatomy and taxonomy of protein structure. $A d v$. Prot. Chem., 34-167.

Sankar, T. V. 2009. Functional properties of fish proteins: A Review. Fish. Technol., 46 (2): 87-98.

Sedlak, J. and Lindsay, R. H. 1968. Estimation of total, protein bound and non-protein sulphydryl groups in tissues with Elman's method. Analytical Biochem., 25: 192-205.

Srikar, L. N. 1979. Protein denaturation in ice stored and frozen marine fish: changes in muscle proteins of croaker fish during ice and frozen storage. Mysore $J$. Agric. Sci. 13: 78-82.

Talwar, P. K. and Jhingran, A. G. 1991. Inland Fishes of Indian and Adjacent Countries., Oxford and IBH Publishing Co. New Delhi, Vol. 1 \& 2. p 1097.

Wang, B. and Xiong, Y. L. 1998. Functional stability of antioxidants washed cryoprotectant treated beef heart surimi during frozen storage. J. Food Sci., 63: 293-298. 
Wang, H., Liceaga-Gesualdo, A. and LiChan, E. C. Y. 2005. Physicochemical properties of muscle and natural actomyosin extracted from farmed Atlantic salmon (Salmo salar) stored at $4^{\circ}$ C. J.Food Biochem., 29(1): 71-87.

Wild, P. J. and Clark, D. C. 1996. Foam formation and stability. pp 110-148. In G. M. Hall (Ed). Methods for testing protein functionality.

Yamaguchi, M. and Sekine, T. 1966. Sulfhydryl groups involved in the active site of myosin adenosine triphosphatase. J. Biochem., 59(1): 24-33.
Yathavamoorthi, R., Sankar, T. V. and Ravishankar, C. N. 2012. Effect of ice storage on the characteristics of common carp surimi. Fish. Technol., 49: 38-44.

Yongswawatdigul, J. and Park, J. W. 2002. Biochemical and conformation changes of actomyosin from threadfin bream stored in ice. J. Food Sci.67:985.

Zar, J. H. 2005. Biostatistical analysis, pp. 663 Dorling Kindersley, India, Pvt, Delhi.

\section{How to cite this article:}

Rohini Mugale, S.B. Patange, V.R. Joshi, G.N. Kulkarni and Shirdhankar, M.M. 2018. Chilled Storage Induced Changes in Functional Properties of Fresh Water Eel (Mastacembelus armatus). Int.J.Curr.Microbiol.App.Sci. 7(03): 693-704. doi: https://doi.org/10.20546/ijcmas.2018.703.081 